\title{
Summary of reconnaissance \\ for uranium in Alaska, 1955
}

By John J. Matzko and Val L. Freeman

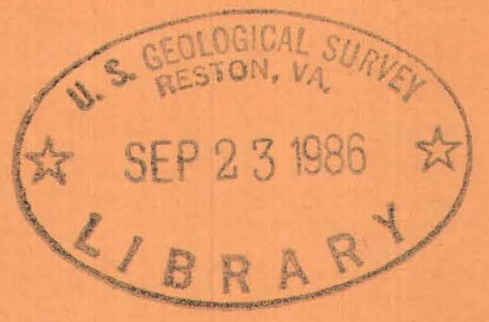

\section{Trace Elements Investigations Report 617}

UNITED STATES DEPARTMENT OF THE INTERIOR GEOLOGICAL SURVEY

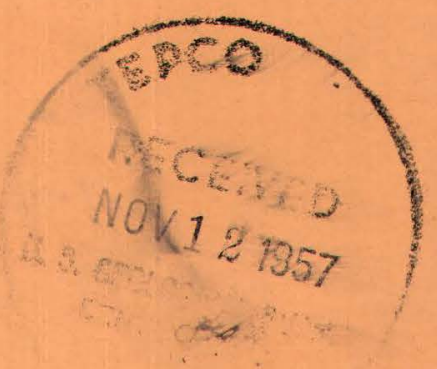


UNITED STATES DEPARTMENT OF THE INTERIOR

GEOLOGICAL SURVEY

SUMMARY OF RECONNAISSANCE FOR URANIUM

IN ALASKA, 1955\%

By

John Jo Matzko and Val L。 Freeman

October 1957

Trace Elements Investigations Report 617

This preliminary report is distributed without editorial and technical review for conformity with official standards and nomenclature。 It is not for public inspection or quotation.

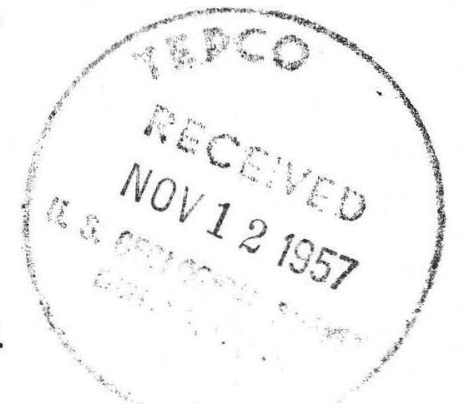

*This report concerns work done on behalf of the Division of Raw Materials of the U。 S. Atomic Energy Commission. 


$$
\text { USGS - TEI-6I7 }
$$

\section{GEOLOGY AND MINERALOGY}

Distribution

No. of copies

Division of Raw Materials, Albuquerque ............ I Division of Raw Materials, Austin ............ 1 Division of Raw Materials, Casper .............. 1 Division of Raw Materials, Denver ............. 1 Division of Raw Materials, Ishpeming ............. 1 Division of Raw Materials, Rapid City ....... . . . . 1 Division of Raw Materials, Salt Lake City ..... . . . . I Division of Raw Materials, Spokane ............. 1 Division of Raw Materials, Washington ........... . 3 Exploration Division, Grand Junction Operations Office - . . 1 Grand Junction Operations Office . . . . . . . . . . . 1 Technical Information Service Extension, Oak Ridge . . . . 6 U。 S。 Geological Survey:

Alaskan Geology Branch, Menlo Park . . . . . . . . . 5 Foreign Geology Branch, Washington ............. . 1 Fuels Branch, Washington .................. 1 Geochemistry and Petrology Branch, Washington ....... 1 Geophysics Branch, Washington ........... 2 Mineral Classification Branch, Washington ......... 2 Mineral Deposits Branch, Washington ............. 1 PoCo Bateman, Menlo Park ................. 1 A。 Io Brokaw, Grand Junction .................. 1 No Mo Denson, Denver 。 . . . . .............. 1 Eo Mo MacKevett, MenIo Park ............. 1 Lo R。 Page, Washington ................... 1

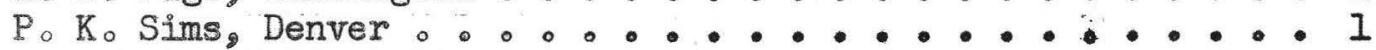
Q. Do Singewald, Beltsville ............... . 1 A。 E。Weissenborn, Spokane ................. 1 TEPCO, Denver o. TEPCO, RPS, Washington, (including master) . . . . . . 2 
CONTENTS

Abstract ..............................

Introduction ............................

Airborne radiometrie reconnaissance. . . . . . . . . . . . . . .

Kotzebue East area. . . . . . . . . . . . . . . . . . . .

Ray Mountains-Hughes-Kokrine Hills area . . . . . . . . . .

Cosna-Noritna RIvers area.....................

White Mountains-Cirele Hot Springs area . . . . . . . . . 12

Fortymile-Eagle-Goodpaster area . . . . . . . . . . . 12

Ground reconnsissance. . . . . . . . . . . . . . . 13

Cirele Hot Springs area .................. 13

Owhat River area. .................... 13

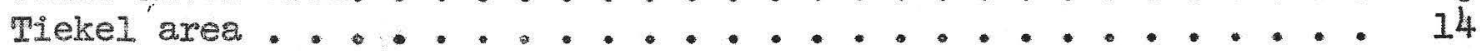

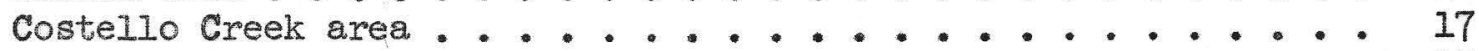

Maclaren River prospect . . . . . . . . . . . . . . 17

Kotzebue East area. . . . . . . . . . . . . . . 19

Geology. ....................... . . . 21

Hockley Hills area............... . . . 21

Kobuk River traverse ................. . . . 22

Iockrood Hills and Zane Hills. . . . . . . . . . . 23

Schratka Mountains and Cosmos Hills areas. . . . . . . 24

Ruby Creek copper prospect. . . . . . . . . . 25

Glennallen to Homer road traverse . . . . . . . . . . 26

Chisik Island. ....................... 28

William Henry Bay area. . . . . . . . . . . . . . 29

Kendrick Bay-Bokan Mountain area. . . . . . . . . . . . 30

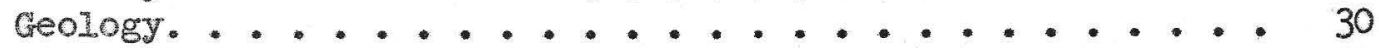

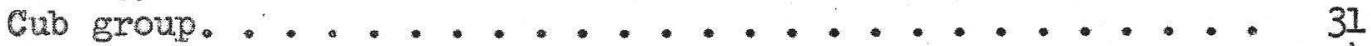

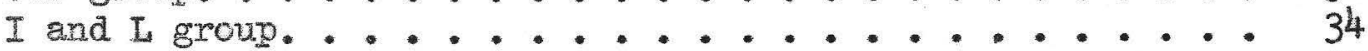

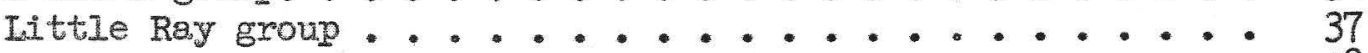

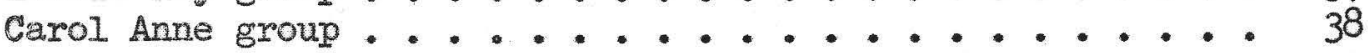

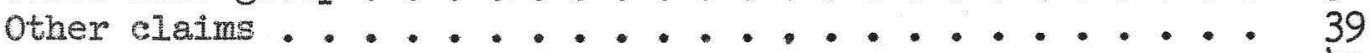

Sumary.
Literature eited . . . . . . . . . . . . . . . . . . . . . . . . . . . . . . . . . . . 41

\section{ILLUSTRATIONS}

Figure 1. Map showing locations of areas investigated for uranium

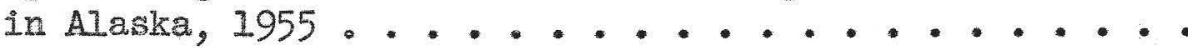

2. Locations of airborne radiometric anomalies and water samples collected in the Owhat River area, Alaska ....

3. Locations of samples from the Costello Creek area, Alaska. 18

4. Loeations of areas investigated in Kotzebue East area. . . 20 
Figure 5. Claim map of the Kendriek Bay-Bokan Mountain area. . . . 32

6. Sketch mag howing radioactivity anomalies on the I and

I claims 3 and $4 \ldots \ldots 35$

\section{TABLES}

Table 1. Radioactivity anomalies located by airborne reconnaissance, 1955 .................... . . 7

2. Uranium content of water samples from Alaska, 1955. . . . 16 
SUMMARY OF RECONNAISSANCE FOR URANIUM IN ALASKA, 1955

By John J. Matzko and Val L. Freeman

ABSTRACT

Reconnaissance for uranium in Alaska during 1955 included airborne radiometric traverses, examination of radioactivity anomalies found during the airborne traverses, examination of prospector leads, and examination of areas that seemed geologically favorable for the occurrence of uranium. The airborne radiometric traverses in central Alaska revealed 33 anomalies considered worth examining. The ground examinations of a few of these anomalies indicated that they were due to radiation from accessory minerals in intrusive granitic rocks. The examination of prospector leads revealed several radioactivity anomalies of interest and one, near Bokan Mountain on Prince of Wales Island, of possible commercial importance.

\section{INTRODUCTION}

The 1955 field season extended from the latter part of May through the middle of october. The writers were aided in the field by M. N. Christensen, H. B. Groom, Jr., W. W. Patton, Jr., I. I. Tailleur, and L. R. Ladwig, all of the U. S. Geological Survey. The work was done on behalf of the Division of Raw Material, U. S. Atomic Energy Commission and aided by logistie support received from the U. S. Army. 
The field work consisted of airborne radiometric traverses, ground reconnaissance of some of the radioactivity anomalies found during the airborne work and of anomalies reported by prospectors and geologists, and a traverse along the Glenn and Sterling Highways. Anomalies found during the airborne traverses were examined on the ground in the Kotzebue East area in the Lockwood Hills and near the mouth of the Kogoluktuk River, and in the Circle Hot Springs area at Cirele Hot Springs. Anomalies reported by prospectors and geologists were examined on the ground in southeastern Alaska at William Henry Bay and at Bokan Mountain, in southern Alaska at Owhat River, Tiekel, and Chisik Island, and in interior Alaska at Costello Creek and Maclaren River。

Different radiation detectors, all of the scintillation type, were used for the air, car, and foot traverses. The anomalies found with the detectors are described in quantitative terms in relation to background radioactivity when possible; however, for many anomalies it is impossible to give quantitative results. Where meaningful background readings were unattainable, the scintillation counter readings are given only when they were of such magnitude that the background is unimportant or when they themselves represent the background as that term is commonly used. None of the anomalies detected from the air were given in quantitative terms sinee the nature of the terrain prevented the maintenance of a constant elevation above the ground. 


\section{AIRBORNE RADIOMETRIC RECONNAISSANCE}

Radiometric reeonnaissance investigations were made with a chartered Cessna-180 using an air speed of about 100 miles per hour while maintaining an average elevation of about 100 feet above the ground. Singleline radiometric traverses were flown because most of the area investigated is of mountainous nature and also partly because large-scale topographic control was not available. Thirty-three anomalies considered worth examining were revealed in central Alaska (table 1).

Table 1.--Radioactivity anomalies located by airborne reconnaissance, 1955

Quadrangle $(1: 250,000)$ North latitude West longitude

Kotzebue East area

\begin{tabular}{lll}
\hline Ambler River & $67^{\circ} 06^{\prime}$ & $157^{\circ} 19^{\prime}$ \\
& $67^{\circ} 17^{\prime}$ & $157^{\circ} 30^{\prime}$ \\
& $67^{\circ} 18^{\prime}$ & $158^{\circ} 14^{\prime}$ \\
Shungnaks & $66^{\circ} 59^{\prime}$ & $156^{\circ} 42^{\prime}$ \\
& $66^{\circ} 22^{\prime}$ & $156^{\circ} 16^{\prime}$ \\
& $66^{\circ} 25^{\prime}$ & $157^{\circ} 01^{\prime}$ \\
& $66^{\circ} 18^{\prime}$ & $156^{\circ} 41^{\prime}$ \\
\hline
\end{tabular}

Ray Mountains-Hughes-Kokrine Hills area

Survey Pass

Shungnak

Tanana

Tanana-Bettles

Bettles

Hughes

Melozitna $67^{\circ} 07^{\circ}$

$66^{\circ} 11:$

$65^{\circ} 52^{\prime}$

$66^{\circ} 00^{\prime}$

$66^{\circ} 21^{\prime}$

$66^{\circ} 30^{\prime}$

$66^{\circ} 33^{\prime}$

$66^{\circ} 03^{\circ}$

$65^{\circ} 35^{\circ}$

$65^{\circ} 27^{\circ}$

$65^{\circ} 10^{\prime}$ $153^{\circ} 21^{\prime}$

$156^{\circ} 04^{\circ}$

$151^{\circ} 02^{\prime}$

$151^{\circ} 02^{\circ}$

$150^{\circ} 27^{\circ}$

$150^{\circ} 27^{\prime}$

$150^{\circ} 16^{\circ}$

$153^{\circ} 55^{\circ}$

$153^{\circ} 58^{\circ}$

$153^{\circ} 48^{\circ}$

$154^{\circ} 04^{\prime}$ 
Table 1.--Radioactivity anomalies located by airborne reconnaissance, 1955 - Continued.

Quadrangle $(1: 250,000) \quad$ North latitude West longitude

Cosna-Nowitna Rivers area

$\begin{array}{llr}\text { Kantishna River } & 64^{\circ} 07^{\prime} & 152^{\circ} 56^{\prime} \\ \text { Ruby } & 64^{\circ} 10^{\prime} & 152^{\circ} 22^{\circ} \\ \text { Ru } & 64^{\circ} 08^{\prime} & 153^{\circ} 14^{\prime}\end{array}$

White Mts.-Circle Hot Springs area

\begin{tabular}{lll}
\hline Cirele & $65^{\circ} 28^{\prime}$ & $144^{\circ} 40^{\prime}$ \\
& $65^{\circ} 36^{\circ}$ & $146^{\circ} 02^{\circ}$ \\
Livengood & $65^{\circ} 38^{\prime}$ & $146^{\circ} 45^{\prime}$ \\
\hline
\end{tabular}

Fortymile-Eagle-Goodpaster area

\begin{tabular}{lll} 
Eagle & $64^{\circ} 29^{\circ}$ & $143^{\circ} 59^{\circ}$ \\
& $64040^{\prime}$ & $143^{\circ} 43^{\circ}$ \\
& $64^{\circ} 46^{\circ}$ & $141^{\circ} 15^{\prime}$ \\
Tanacross & $64^{\circ} 47^{\prime}$ & $141^{\circ} 59^{\prime}$ \\
& $63^{\circ} 39^{\circ}$ & $142^{\circ} 14^{\circ}$ \\
& $63^{\circ} 44^{\circ}$ & $141^{\circ} 30^{\circ}$ \\
& $63^{\circ} 39^{\circ}$ & $141^{\circ} 20^{\circ}$ \\
& $63^{\circ} 39^{\prime}$ & $141^{\circ} 34^{\circ}$ \\
\hline
\end{tabular}

In addition to the airborne radiometric reconnaissance conducted by the writers, some similar reconnaissance was conducted by other members of the Geologieal Survey in conjunetion with magnetic survey work. Radioactivity anomalies were located during this work in the Russian Mountains-Owhat River area and on Chisik Island. Both of these areas were examined on the ground. 


\section{Kotzebue East area}

Radjometric traverses were flown in an area east of the town of Kotzebue, and herein called the Kotzebue East area (fig. I), to outline areas of anomalous radioactivity for ground investigation.

The area examined is underlain by sedimentary rocks of Tertiary age, sandstone and shale of Cretaceous age, the Noatak sandstone of Mississippian age, limestone and metamorphic rocks of Silurian age, and granitic rocks thought to be of Jurassie age (Smith and Mertie, 1930).

of the seven radioactivity anomalies found in the Kotzebue East area (table 1) only one was examined on foot; it was found to be due to the radioactivity of granite. This anomaly is near the mouth of the Kogoluktuk River $\left(66^{\circ} 59^{\prime} \mathrm{N}, 156^{\circ} 42^{\prime} \mathrm{W}_{.}\right)$and is due to a gneissic granite containing 0.005 percent equivalent uranium. The other anomalies in the Kotzebue East area were not checked because logistic support was unavailable.

\section{Ray Mountains-Hughes-Kokrine Hills area}

The Ray Mountains and Kokrine Hills lie between the Yukon and Koyukuk Rivers to the east and southeast of the village of Hughes on the Koyukuk River (fig. 1). Iittle is known about the geology of the Ray Mountains except that they contain granite and metamorphic rocks of Paleozole(?) age, and are bounded on the east and west by greenstone (Eakin, 1916, pI. II). Many prominent pinnacles believed to be granite were seen from the air. The Kokrine Hills contain large areas of rock of possible Paleozolc age; smaller, granitic bodies of Mesozoic 


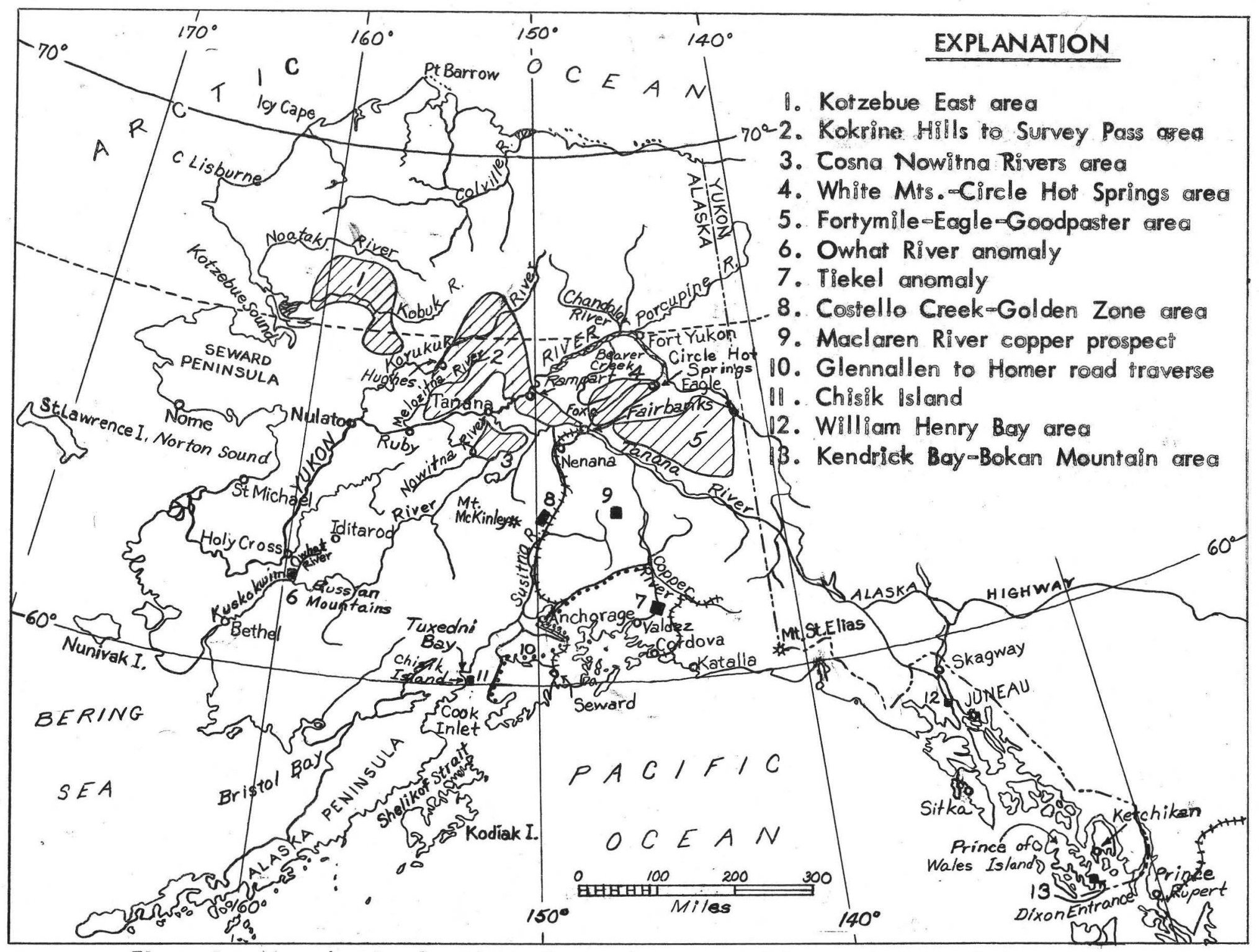

Figure 1.--Map showing locations of areas investigated for uranium in Alaska 1955 
age, and others of Eocene(?) age; a metamorphic complex, including quartzites, of midale Paleozoie age; and in the western part of the mountains, conglomerates, sandstones, and shales of Mesozoic, probably Late Cretaceous age (Eakin, 1916). Placer gold is the only mineral eurrently mined in the area, although argentiferous galena in lode deposits and stream tin (cassiterite) also oceur. Placer mining in the area was begun about 1911.

Elieven anomalies (table 1) were found in the region of the Ray Mountains but none were checked, beeause of the lateness of the season and difficult access to the areas. From the air most of the anomalies appeared to be related to outerops of granite and may be caused by radioactive accessory minerals in the granites.

\section{Cosna-Nowitna Rivers area}

The Cosna Nowitna Rivers area (fig. I) is the highland area that forms a northeastward extension of the Kuskokwim Mountains. It lies south of the town of Tanana that is located at the junetion of the Tanana River with the Yukon River. The area is underlain by Mesozoic sedimentary rock and by Tertiary rhyolitic and andesitic lava and tuff intruded by granite (Eakin, 1918).

Three anomalies (table 1) were found south and southwest of the Cosna-Nowitna divide in an area of voleanic rocks intruded by granite. No field examinations were made. 


\section{White Mountains-Circle Hot Springs area}

An airborne radiometrie reconnaissance was made from Fairbanks north to the White Mountains and then northeast to Circle Hot Springs (fig. 1). Rock types examined were the Birch Creek schist of Precambrian age, undifferentiated chert, quartzite; and shaly limestone of Devonian and possibly Silurian age, and granite of Mesozoic age (Mertie, 1937). Poorly exposed Tertiary sedimentary rocks are also present.

The four anomalies found in the area (table I) are believed to be related to outerops of granite; however, only one of them was investigated on the ground. Samples of metasedimentary rock that according to prospectors were collected from near the other anomalies contain about 0.005 percent equivalent uranium. The investigated anomaly is about half a mile west of Circle Hot Springs.

Radioactive argentiferous galena prospect trenches containing up to 0.025 percent equivalent uranium, on the divide between Fox and Flume Creeks in the Fairbanks district, directly north of the town of Fox, were specifically checked from the air, but no anomalies were noted at about 50 feet above the ground. (White, and others, 1952, table 2.)

\section{Fortymile-Eagle-Goodpaster area}

The Fortymile, Eagle, and Goodpaster areas (fig. 1) lie between the Yukon and Tanana Rivers east of Fairbanks. The traverses crossed areas of sandstone, shale, and conglomerate of Tertiary age, the Birch Creek schist of Precambrian age, granite and quartz diorite of Mesozoic age, rhyolite and dacite of Tertiary age, and lavas of late Tertiary and 
Quaternarý age (Mertie, 1937).

Some of the eight anomalies found, oceur near the contact of granite of Cretaceous age and rhyolitic flow rocks of Tertiary age. None of them were examined on the ground.

\section{GROUND RECONITISSAIVCE}

\section{Cirele Hot Springs area}

A small area near Circle Hot Springs was traversed in an attempt to locate the source of a sharp anomaly noticed with airborne equipment. The Cirele Hot Springs area was studied by Nelson, West and Matzko (1954), and radioactive accessory minerals are known from the granite of the area. On the airborne instrument, the anomaly gave readings of about twice the unusually high background that is present over the granite. An area on the ground of about one-fourth of a square mile was traversed with scintillation counters. Fleven traverse lines each about half a mile long and spaced about 250 feet apart were run in an easterly direction, and one line was run through the center of the area in a northerly direction. Nothing was found during ground traverses that would explain the sharp anomaly noticed from the air. The readings obtained during the ground traversing were 0.01 to $0.02 \mathrm{mr} / \mathrm{hr}$, except for one small area that gave readings of $0.03 \mathrm{mr} / \mathrm{hr}$. The higher reading seemed to correspond with an area of finetextured granite.

Owhat River area

The Owhat River is a tributary of the Kuskokwim River that flows 
southward along the west side of the Rusaian Mountains. Anomalous radioactivity in this area (fig. 2) was reported to the writers by other members of the U. S. Ceological Survey who noticed it in airborne traverses made on the west and north sides of the Russian Mountains. Iwo anomalies located near the Owhat River, about 12 airline miles north of its mouth, were seleeted for field ehecking.

Seintillation-counter traverses on the grovnd indicated an average of about $0.009 \mathrm{mr} / \mathrm{hr}$ and did not reveal any anomalous radioactivity. The exposed material, oceurring as rubble, consists predominantly of finegrained and porphyxitic basic Igneous rocks and minor amounts of granite. Analyses of water samples colleeted from small streams draining the examined areas are show in table 2 and sample locations are shown on figure 2 .

During 1952 an examination of a nearby area was made (West, 1954) after metazewnerite was identified in a concentrate from an arsenicmeoper vein collected in the upper turnel of the Konechney prospect. The prospect is on Mission Creek between the owhat River and the Russian Mountains. About a mile northeast of the Konechney prospect, dump matexial from a group of claims on Cobalt creek contains copper, gold, silver, and tin. Granite from the Russian Mountains contains up to 0.005 percent equivalent uranium.

\section{Tiekel area}

In the summer of 1955 a report by prospectors of radioactivity adjaeent to the Richardson Highway at about Milepost 55, near Tiekel (fig. 1), resulted in the staking of many claims. The bedrock of the general area Is a contorted elaty graphitic graywacke of Cretaceous age that is cut by 


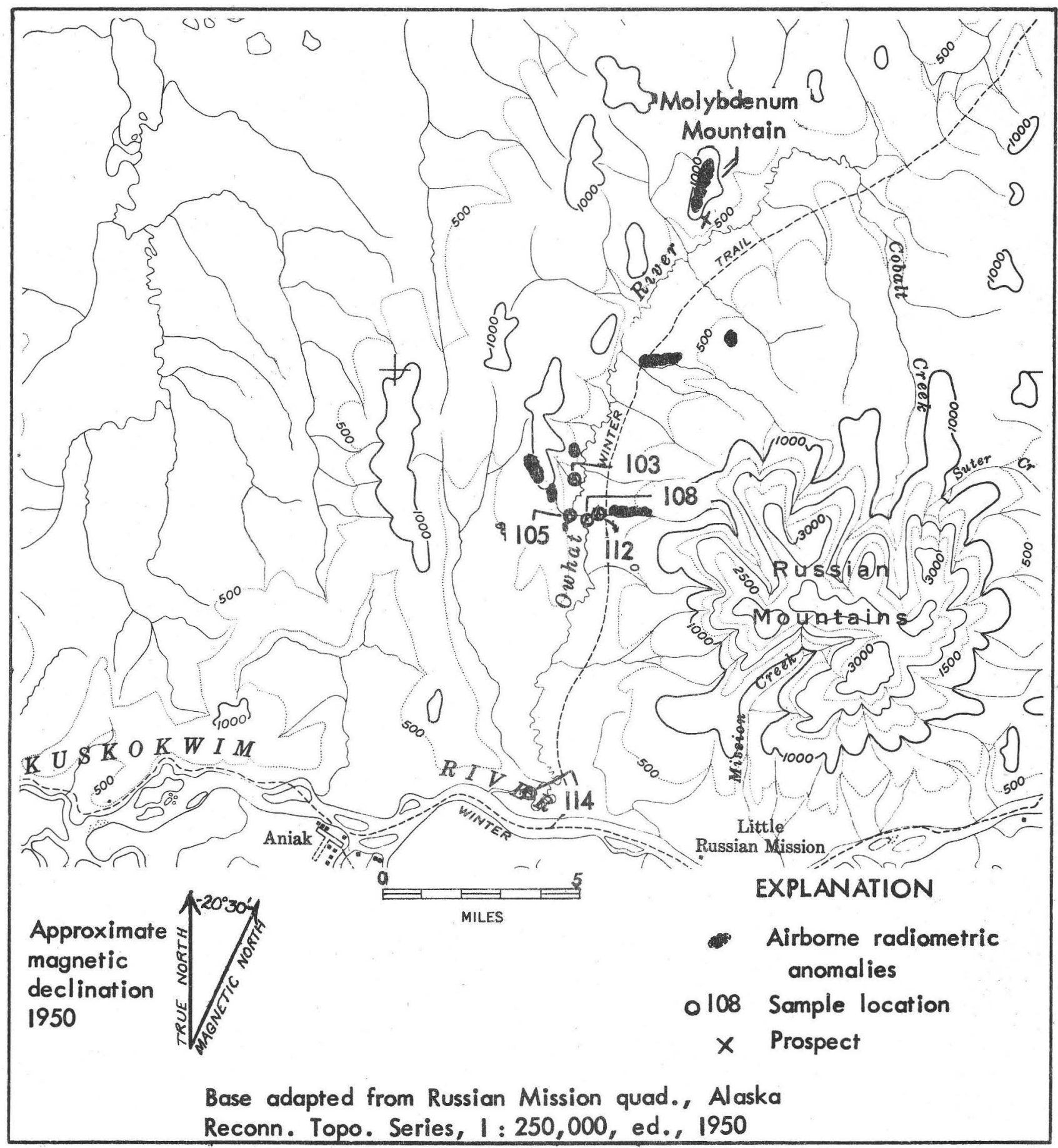

Figure 2.--Locations of airborne radiometric anomalies and water samples collected in the Owhat River grea, Alaska 
Table 2.--Uranium content of water samples from Alaska, 1955
Field Ho
Laboratory no.
U (parts per
Owhat River area I/ billion)
Location

\begin{tabular}{|c|c|c|c|}
\hline $55 \mathrm{AMz}-103$ & 145,634 & 0.1 & $\begin{array}{l}\text { 7th rt. Iimit trib. to } \\
\text { Owhat River. }\end{array}$ \\
\hline 105 & 145,635 & .1 & $\begin{array}{l}\text { 8th rt. limit trib. to } \\
\text { Owhat River. }\end{array}$ \\
\hline 108 & 145,636 & .2 & $\begin{array}{l}\text { 9th left limit trib. to } \\
\text { Owhat River, 100 ft. up- } \\
\text { stream from mouth. }\end{array}$ \\
\hline 112 & 145,637 & .3 & $\begin{array}{l}\text { 9th left limit trib. to } \\
\text { Owhat River, about } 0.5 \\
\text { mile upstream from } \\
55 \mathrm{AMz}-108 \text {. }\end{array}$ \\
\hline 114 & 145,638 & .1 & $\begin{array}{l}\text { On Owhat River, about } 1 / 4 \\
\text { mile from mouth (upstream), } \\
\text { Taken for background. } \\
\text { sample. }\end{array}$ \\
\hline
\end{tabular}

\begin{tabular}{cccc}
\hline Maclaren River prospect $2 /$ \\
\hline 1 & 144,484 & $<0.2$ & $\begin{array}{r}\text { First stream above Alaska } \\
\text { Copper mine adit. } \\
\text { Main stream, about 250 ft. } \\
\text { upstream from mine adit. } \\
3\end{array}$ \\
4 & 144,485 & $<.2$ & $\begin{array}{c}\text { Sump in mine, at first } \\
\text { crosseut. } \\
\text { Crosscut } 3 \text { in mine, } \\
\text { at face. } \\
\text { Crosscut } 2 \text { in mine, } \\
\text { at face. }\end{array}$ \\
\hline
\end{tabular}

\begin{tabular}{ccc} 
Costello Creek area 1$]$ \\
\hline $55 \mathrm{AMz}-2$ & $<.1$ & $\begin{array}{r}\text { First left limit tributary } \\
\text { stream to Costello Creek. }\end{array}$
\end{tabular}

Chemieal analyses by U. S. Geological Survey, Washington, D.C.

If Roberta Smith, analyst

2) Ann Sweeney and Glen Edgington, analysts 
numerous quartz veins and by dikes and sills of diorite porphyry (Moffit, 1935).

A scintillation-counter traverse of the area gave a maximum reading of $0.02 \mathrm{mr} / \mathrm{hr}$ on the slaty graywacke. Samples of the graywacke that were tested on a laboratory sealer contained less than 0.001 percent equivalent uraniun. A felsite dike, about 4 feet wide, gave a reading of $0.015 \mathrm{mr} / \mathrm{hr}$. Interest in the area has lessened, and no further exploratory work by prospectors is contemplated, as far as is known.

\section{Costello Creek area}

A brief investigation was made in the Costello Creek area (fig. 1), where a sample of slightly radioactive coal (43AWg251) (fig. 3) was collected by geologists studying the coal fields. Costello Creek is a tributary of the west fork of the Chulitna River. It is located west of the Broad Pass station on the Alaska Railroad in the southern foothills of the Alaska Range. The area is underlain by coal-bearing roeks of probable Eocene age (Ross, 1933).

No radioactivity anomalies were found in the limited amount of exw posures traversed. A water ample (55AMz2), collected from the stream draining the area from which the radioactive coal was taken (fig. 3 and table 2), contains less than 0.1 part per billion uranium. Heavy surface runofe at the time of sampling likely diluted the normal uranium content of this stream.

\section{Maclaren River prospect}

A scintillation-counter traverse was made and samplea were collected 


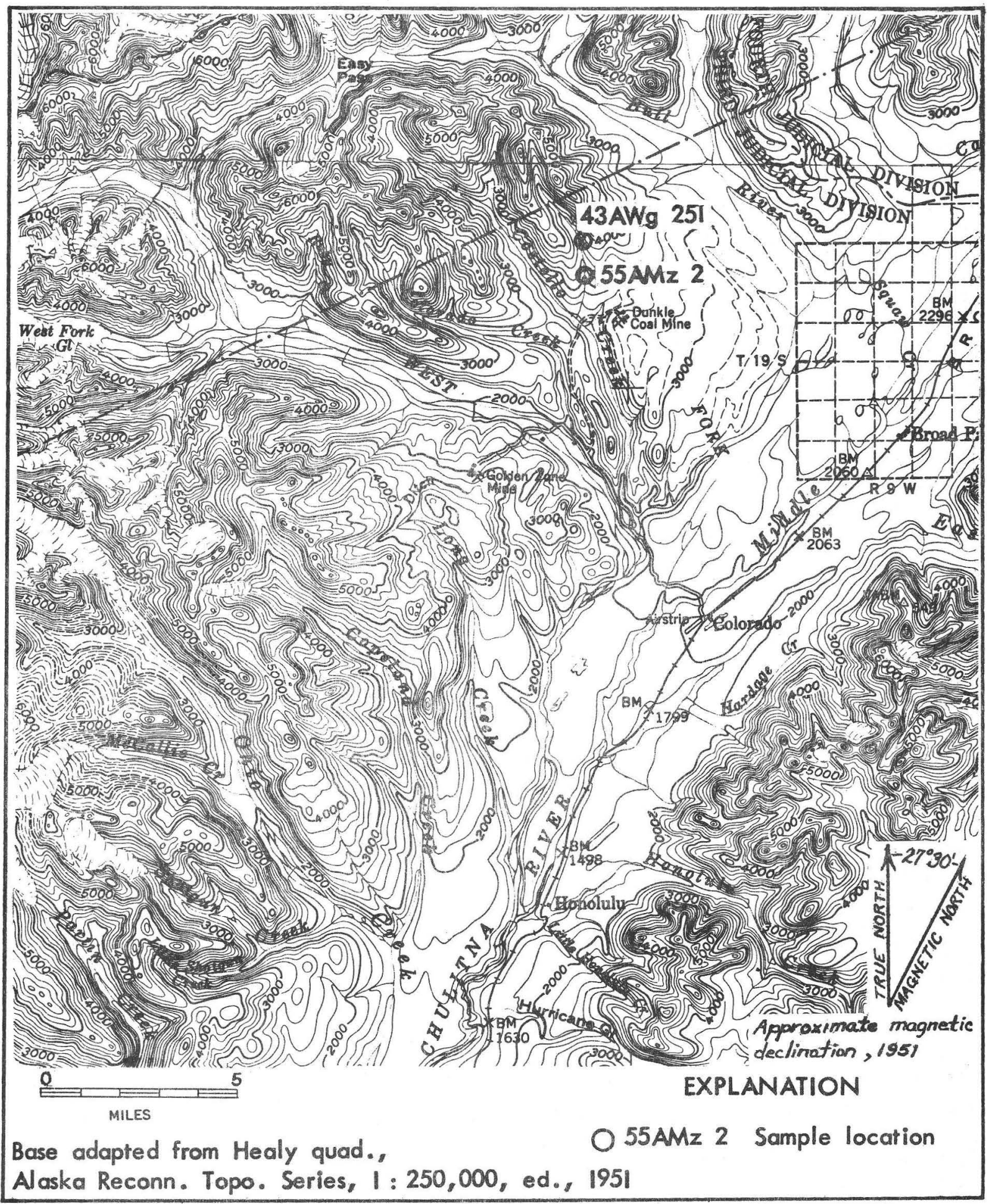

Figure 3.-alocations of samples from the Costello Creek area, Alaska 
at the Kathleen-Margaret copper prospect (Chapman and Saunders, 1954), property of the Alaska Copper Mines Company, Maelaren River, near the terminus of the Maclaren Glacier, Mt. Hayes quadrangle, locality 9 (fig. 1). One day was spent on the property in cooperation with geologists conducting a Defense Minerals Exploration Administration examination.

Moffit (1912) reports the bedrock in the general area to be amygdaloidal lava flows of probable Pennsylvanian age, consisting principally of diabase and basalt, with tuffaceous and shaly beds. Diorite In the area is probably of Late Jurassic or Cretaceous age and is believed to be the source of the gold found in other parts of the district.

A prominent quartz vein containing primary and secondary copper minerals, and numerous prospect trenches were examined for radioactivity. A maximum reading of $0.003 \mathrm{mr} / \mathrm{hr}$ was obtained on the quartz-eopper vein. A traverse of the mine revealed a maximum of $0.002 \mathrm{mr} / \mathrm{hr}$. Negligible amounts of uranium were found in five water samples collected in the mine and also from two nearby streams. The waters contain a maximum of 0.2 part per billion uranium (table 2).

\section{Kotzebue East area}

Several areas in the northern part of the Koyukuk geosyncline (Payne, 1955) region or Koyukuk Cretaceous basin (Patton and Bickel, 1956a) in westcentral Alaska, as well as several small areas to the north were investigated during the early part of the summer of 1955. The region is shown generally as part of the Kotzebue East area on figure 1, locality 1, and the extent of the geosyncline as well as the areas examined is shown on figure 4. The investigations for radioactive materials were made concurrently with other 


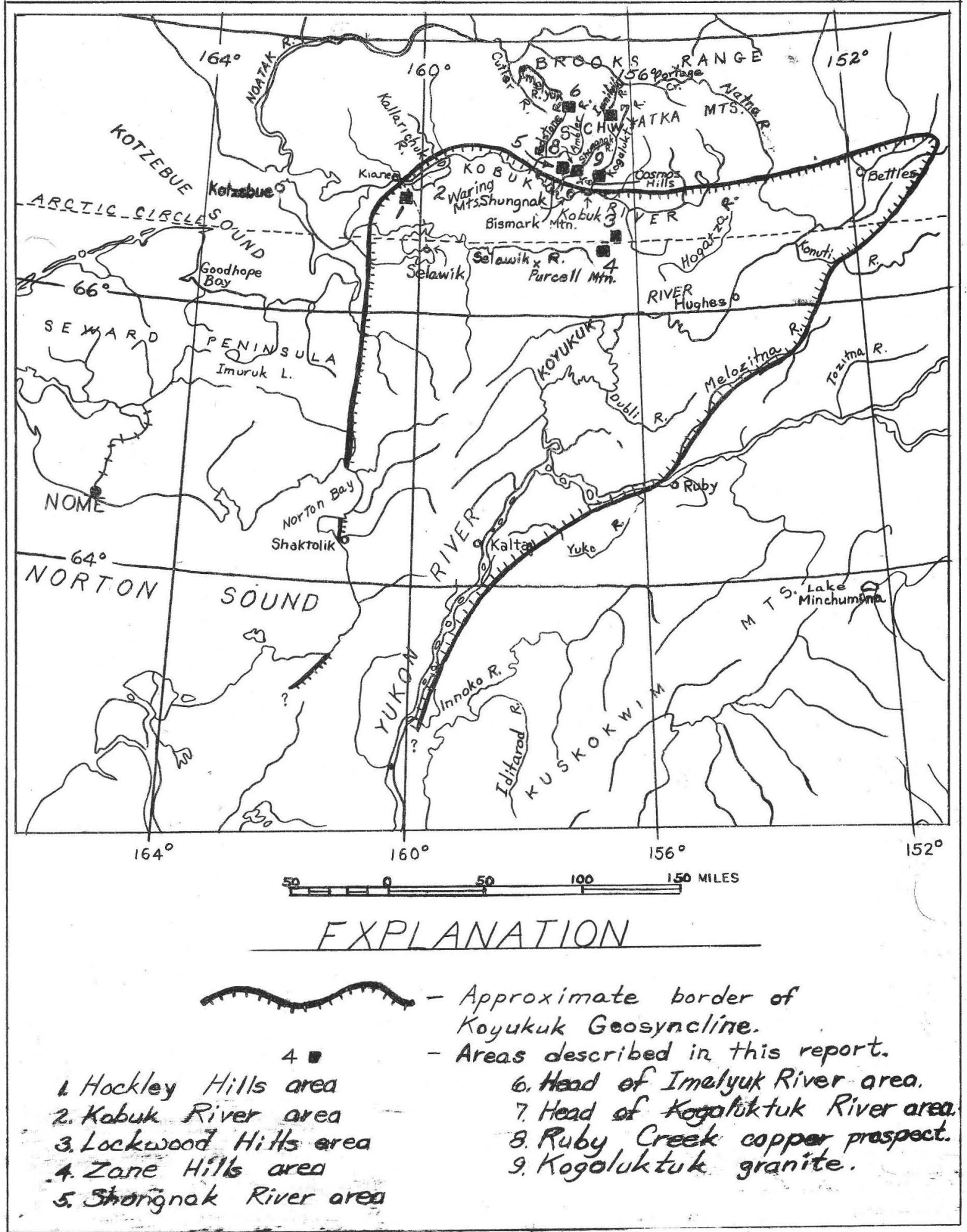

Figure 4--Locatians of areas investigated in Kotzebue East area. 
investigations in the area by the U. S. Geological Survey.

\section{Geology}

Parts of the Koyukuk Geosyneline region were visited by Schrader (1904) and by Smith and Eakin (1911), but the region as a whole remained geologically unknown until a study was started in 1954 by Patton and Bickel (1956a, 1956b). Before the start of current investigations by Trilleur the area investigated north of the region was not studied, except for a part of the Cosmos Hills (Coats, 1944).

The Cretaceous sedimentary rocks in the Koyukuk Geosyncline region are divided into a border facies and an interior facies, each of which is divisible into two or more map units (Patton and Bickel, 1956a). The border facies is believed to grade into the interior facies, but an exact correlation is not possible. The rocks of the border facies are predominantly conglomerates, sandstones, and related mudstones, many of which contain much volcanic material; those of the interior facies are predominantly graywackes and volcanies cut by shallow intrusive rocks of basic and intermediate composition. The rocks north of the basin are metamorphosed sedimentary rocks of Paleozoic age or older and granitic intrusive rocks.

Hockley Hills area.

The Hockley Hills, a westward extension of the Waring Mountains, are in the northern part of the Selawik quadrangle (fig. 4). The area investigated is adjacent to Portage Creek along the winter trail between Kiana and Selawik. Rocks assigned to the upper and lower units of the Koyukuk 
geosyncline border facles were traversed. The rocks in this area are mostly conglomerates with a graywacke matrix, mudstone, graywacke, and impure black shale. These sediments appear to have been derived in large part from shallow intrusive and extrusive rocks of dioritic composition. A few of the pebbles in the conglomerates are of older graywacke and vein quartz.

None of the rocks are more than weakly radioactive; the radioactivity tends to be inversely proportional to the grain size. A sample of black shale, the most radioactive rock type found, contains 0.003 percent equivalent uranium. The Hockley Fills must be considered as unfavorable for radioagtive mineral deposits of both sedimentary and vein types. The sediments are without exception of low porosity and permeability because of original high content of clay-sized material and because of compaction and strong induration since deposition. As no intrusive bodies were found, the area. is considered unfavorable for vein deposits.

Kobuk River traverse

The outerops along the north bank of the Kobuk River were traversed from near the mouth of the Kallarichuk River to Kiana, a distance of about 25 miles. Most of the traverse was on rocks assigned to the upper unit of the border facies that consist of conglomerate characterized by pebbles of white quartz, sandstone, earbonaceous sandstone, and shale. Coal and minor amounts of altered tuff were also examined. Near Kiana mica schist of Paleozoic age was tested. The most radioactive of the sedimentary rocks are the carbonaceous shales and sandstones, but even these are only weakly radioactive. In sandstone ledges stained with limonite, the highest radioactivity was where the limonite had been removed along fractures and from 
irregular blotches; however, the difference in amount of radioactivity was barely measurable. The mica schist of Paleozoic age is somewhat less radioactive than the carbonaceous sediments but more radioactive than the conglomerates .

The portion of the upper unit of the border facies of Cretaceous sediments that is characterized by white quartz pebble conglomerates, carbonaceous sediments, and coal beds appears to be the most favorable for deposits of radioactive materials of any of the sediments seen in the Kotzebue East area. The coarse-grained beds are better sorted and more porous than other beds in the area, and contain carbonaceous material. They are locally cross-bedded and many are stained with limonite. These features are characteristic of sediments that are host rocks for sedimentary-type uranium deposits in the Colorado Plateau and Rocky Mountain regions of the United States.

\section{Lockwood Hills and Zane Hills}

The Lockwood Hills are about 35 miles southeast of the village of Shungnak on the Kobulk River. The Zane Hills are about 15 miles south of the Lockwood Hills. Both areas are shown on the Shungnak 1:250,000 quadrangle. The sedimentary rocks exposed in the Lockwood and Zane Hills are assigned to four units of the interior facies (W. W. Patton, Jr., personal communication). They have been intruded by dioritic rocks in the Lockwood Hills and by granitic rocks in the Zane Hills. The sedimentary rocks in the upper half of the unit are graywackes with a small to very large amount of tuffaceous material. Volcanic rocks including tuffs, breccias, and flows are present in the lower half of the unit. These rocks are only slightly 
radioactive.

The intrusive rocks in the Lockwood Hills are diorite porphyries that occur in small stocks. Plagioclase phenocrysts are the only grains that are megascopically recognizable. The diorite porphyries, although much more radioactive than the surrounding sedimentary rocks, contain only 0.003 percent equivalent uranium. Granitic bodies are present in the Zane Hills and to the west to Pureell Mountain. These intrusive rocks give anomalies that were detected from the air, but samples collected contained no more than 0.004 percent equivalent uranium.

Because of their low permeability, the sedimentary rocks of the Lockwood and Zane Hills are considered unfavorable for sedimentary-type uranium deposits. The large number of intrusive stocks, some of granitic composition, indicates that the area may contain some vein deposits. Veins of quartz are common in the Zane Hills, but all of the veins observed were barren of sulfide minerals and not abnormally radioactive.

\section{Schwatka Mountains and Cosmos Hills areas}

The areas investigated in the Schwatka Mountains and Cosmos Hills are vithin the Shungnak and Ambler River quadrangles. Previous geologic work in these areas consists of reconnaissance mapping along the major rivers (Smith and Mertie, 1930) and detailed mapping in a few small areas in the Cosmos Hi11s near asbestos deposits (Coats, 1944). Smith and Mertie (1930) show the areas Investigated as underlain by highly metamorphosed lower Paleozoic or older rocks and Silurian sedimentary rocks.

During the present investigations, traverses were made from camps established on the Shungnak River near Bismark Mountain, in the area near 
the headwaters of the Imelyuk River, and in the area between the headwaters of the Kogoluktuk and Ipmiluik Rivers (fig. 4). Short visits were made to the Ruby Creek copper prospect and to an area of granite near the mouth of the Kogoluktuk River. All of the rooks traversed are moderately to strongly metamorphosed and include mica, chlorite, and graphite schists; limestone; sehistose conglomerates; metamorphosed basic intrusives (diabase); serpentine; and gneissic granite. Of the rock types only the gneissic granite near the mouth of the Kogoluktuk River was more than slightly radioactive. Samples from this rock contain as much as 0.005 percent equivalent uranium. As would be expected, the least radioactive of the rock types was the serpentine and associated asbestos.

Ruby Creek copper prospect.--A copper prospect that contains sulfide minerals in limestone is on Ruby Creek about 12 miles north of the village of Shungnak; it was visited for a few hours incidental to other work. This prospect was reported to contain radioactive material in veins with chalcopyrite, bornite, galena, sphalerite, and pyrite. It was investigated in 1949 (White, 1950), and ore samples collected at that time contained no more than 0.007 percent equivalent uranium, concentrated principally in the sphalerite. Additional investigations were not recommended until more work had been done at the prospect. Unfortunately when the prospect was investigated on JuIy 21, 1955, the owner, Rinehart Berg, was not present; and, it is not certain, due to the limited time spent on the prospect, that ail the radioactive areas were found. After the prospect was visited in 1949, much of the surface covering was stripped off by bulldozer but no deep euts were made. A traverse of the stripped area revealed a radioactivity anomaly about 25 feet long and about one foot wide corresponding to a much weathered 
vein. The vein of limonite(?) with minor secondary copper carbonates strikes north and continues beyond the limits of the anomaly both north and south. North of the anomaly, but not in the vein, light-purple coarsegrained fluorite was found in white quartz.

The most radioactive parts of the vein gave readings of 0.20 to 0.30 $\mathrm{mr} / \mathrm{hr}$ on the scintillation counter, compared to a reading on adjacent rocks of about $0.01 \mathrm{mr} / \mathrm{hr}$. A sample collected for further study from the most radioactive area contains 0.02 pereent equivalent uranium. No uranium mineral was recognized in the highly weathered fine-grained sample. Because of the high degree of weathering, it is felt that an equivalent-uranium content of 0.02 percent may be of significance in indicating the presence of ore-grade material beneath the zone of weathering. However, as the weathering likely extends to considerable depth, and because the vein is narrow and the prospect remote, it does not seem likely that the prospect can be mined for uranium alone.

\section{Glennallen to Homer road traverse}

The radiometric traverse between Glennallen and Homer on the Glenn and Sterling Highways was incidental to examining the sedimentary rocks that erop out along the route (fig. 1). A previous road traverse was made in 1947 with less sensitive equipment (Moxhom and Nelson, 1952)。Again, as in 1947 , no radioactivity was detected during the traverse. The detecting instrument used during the traverse was a Jeep-mounted scintillation counter that was connected to a continuous recorder. The sediments that appeared most similar to the host rocks of sedimentary uranium deposits in the Colorado Plateau region were a sandstone in the Chickaloon formation 
and the sandstones and coals of the Kenai formation.

The Chickaloon formation is a nonmarine sequence of Eocene age that consists of shale, sandstone, conglomerate, and coal beds. The favorableappearing sandstone erops out adjacent to the east end of the highway bridge where the Glenn Highway crosses Moose Creek in an area mapped by Waring (1934). It is a "salt and pepper" sandstone, medium gray to light brown, medium grained and well sorted. It is cross bedded on a medium scale and contains pockets of gray clay chips and plant fragments as well as several thin beds of gray shale. Locally the sandstone is stained brown by iron oxides. The only feature of the sandstone that would seem to make it unfavorable for uranium deposits is the high degree of induration. The sandstone is well compacted and cemented, with resulting low permeability and porosity. No radioactivity anomalies were found.

The Kenai formation of Eocene age is also nonmarine in origin and is composed of interbedded sandstone, shale, conglomerate, and lignite. The sandstone beds are slightly less indurated than the sandstone in the Chicka-Ioon formation, and they are evenly bedded and apparently continuous over large areas. The formation was examined at selected localities between Homer and Kenai along the east shore of cook Inlet. In this area subsurface water is abundant and springs are common along a sea cliff cut into the formation. The water moving through the continuous sandstone beds probably would leach uranium from the rock rather than form deposits, but local areas of restricted subsurface water flow might be favorable sites for uranium deposition. The subsurface water conditions in the Kenai formation suggest, by analogy with areas in the Dakota-Montana region of the U. S. and with the Colorado Plateau, that the tops of lignite beds might be favorable sites for 
uranium deposition. Where exposed the rocks of the Kenai formation were tested for radioactivity with special attention paid to the sandstone and the lignite beds. No radioactive areas were found.

\section{Chisik Island}

Chisik Island is near the western shore of Cook Inlet at the mouth of Tuxedni Bay (fig. 1). The northern part of Chisik Island was visited to investigate a radioactivity anomaly reported to the writers by other members of the Geological Survey. During the two days spent on the island a radiometric traverse was made along the sea cliff for several miles on each side of the island from the northern tip of the island.

Chisik Island, described by Moffit (1927), is composed of marine sedimentary rocks of geosynclinal types that include the upper part of the Chinitna shale and the Naknek formation of Late Jurassic age. The sedimentary rocks dip moderately to the southeast. Only the Chinitna shale and the Chisik eonglomerate member of the Naknek formation were examined.

The Chinitna shale is slightly fissile sandy shale or mudstone and contains some beds of locally conglomeratic sandstone, graywacke, and limestone. It is moderately fossiliferous. The Chisik conglomerate member is a coarse conglomerate several hundred feet thick, composed predominantly of granitic and dioritic boulders up to 2 feet in diameter in a graywacke matrix that may contain andesitic tufe.

During the traversing on Chisik Island, no radioactivity was noticed. The anomaly had been detected from the air by a high-flying plane of the Geological Survey and was reported to be near the northern part of the sea cliff. The anomaly undoubtedly was due to the topographic effect of the 
steeply rising (2,600 feet in 1 mile) hills, combined with the mass effect of radioactivity from the granitic material in the thick Chisik oonglomerate member of the Naknek formation.

\section{William Henry Bay area}

William Henry Bay is on the west side of the Lynn Canal about 45 miles northwest of Juneau (fig. 1). The highest radioactivity anomaly known in the area is on the Lucky Six group of claims located about one mile north of the bay at an altitude of about 1,900 feet. The anomaly as noted from the air by the prospectors is about 3,800 feet long and lies along the top of a small ridge that is partly covered with low vegetation. The prospect has been explored by several shallow pits and one diamond-drill hole, all In one small area within the much larger area of the anomaly, but the prospeeting has not been sufficient to permit an accurate evaluation of the property.

The bedrock underlying the area at the Lucky Six group that was examined is metamorphosed Igneous rock. It is predominantly feldspar with streaks of white mica. The only identified radioactive mineral is thorianite, which oceurs in small reddish patehes in the bedrock. Partially oxidized pyrite was also seen. Material of 0.2 percent equivalent uranium is reported from the prospect, but no minable quantity of rock of this grade was known at the time of the examination. The operators plan further work, including more drilling.

Ten water samples were taken along Lynn Canal from ten small streams that drain the area of the anomaly. The streams enter Lynn Canal along a distance of about one mile. All of the samples were found to contain less 
than 1 part per billion uranium.

Kendriek Bay-Bokan Mountain area

The Kendrick Bay-Bokan Mountain area is near the south end of Prince of Wales Island approximately 45 miles southwest of Ketehikan, Alaska (fig. 1). The area is shown on the Dixon Entrance (D-I) quadrangle which is available in preliminary form at a scale of 1:40,000. Prospecting activity extends from the north slope of Bokan Mountain southwest to Gardner Bay, a distance of about ten miles. The area is characterized by steep hillsides that are covered by dense vegetation below an altitude of about 900 feet and partly eovered by vegetation between 900 feet and 1,500 feet. The top of Bokan Mountain is about 2,600 feet above sea level and is two miles from the shore of the West Arm of Kendrick Bay. The area is characterized by abundant rainfa.l; and, although weather conditions are often unpleasant, prospecting is possible during a.l but the winter months. The area is aceessible by boat or by planes equipped with floats. Travel by foot away from the shores of the bays and lakes is difficult even on the few trails built by the prospectors.

Geology

Bokan Mountain and most of the area between Bokan Mountain and the West Arm of Kendrick Bay is underlain by granite. The north shore of the West Arm is underlain by diorite eut by andesite dikes. The granite is medium grained; many quartz crystals are larger than the feldspar crystals. Potash feldspar is dominant over plagioclase feldspar; and, in hand speeimens, the mafic mineral seems to be hormblende. Quartz forms about 25 
percent of the rock. Exeept near the margin of the intrusive, the granite is quite uniform in texture and composition. It is fractured on a large scale and has several sets of prominent joints; locally it is eut by pegmatite dikes, quartz veins, and fine-grained basie dikes. As yet no detailed geologie mapping or petrography has been done in the Bokan Mountain area, and the area between Kendrick Bay and Gardner Bay is geologically unknown. The entire Kendrick Bay-Bokan Mountain area was overridden by glaciers in the reeent past.

Areas of radioactivity that have been examined by personnel of the Ceological Survey are on the Cub, I and L, Little Ray, and Carol Anne groups of claims (fig. 5). Other claims that have not been examined are located north and west of Bokan Mountain, and south of the West Arm of Kendriek Bay.

\section{Cub group}

The Cub group (Ross-Adams lode) was staked in the spring of 1955 by Don Ross and Keldron Adams after an anomaly was detected from the air. It consists of 12 and a fraction claims located on the southeastern slope of Bokan Mountain (fig. 5). The radioactive deposit on the Cub number 1 claim is at an altitude of about 925 feet above sea level on a topographic bench nearly barren of vegetation. The deposit has a northerly trend and is about 150 feet long and about 30 feet wide. In and near the deposit the granite has been altered and subsequently weathered. The alteration has noticeably affected the mafic minerals of the granite for a distance of about 100 feet from the deposit. The outerops of the deposit are stained with iron oxides produced during weathering. 


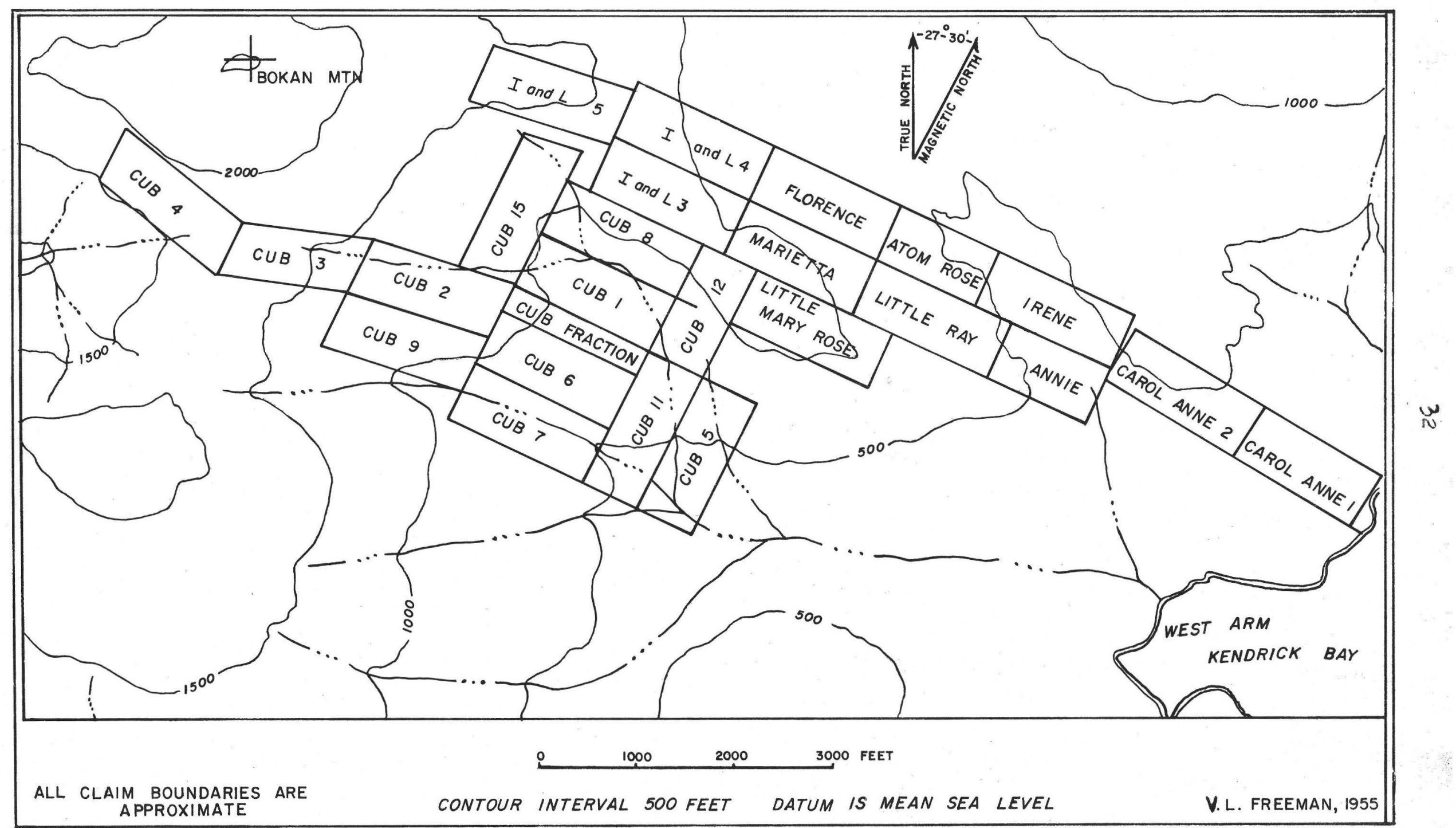

FIGURE 5.-- CLAIM MAP OF THE KENDRICK BAY - BOKAN MOUNTAIN AREA 
A elosely spaced set of joints (trending $\mathbb{N} .10^{\circ}-20^{\circ}$ W.) is prominent at the deposit and much less well developed elsewhere, but other joint sets show no relationship to the deposit. The prominence of the one set of joints at the deposit seems to be the result of localized alteration and weathering. Although the joints do not appear to be the controlling feature of the localization of the deposit, they may be the expression of a hidden fault that is the controlling feature. On aerial photographs of the area an eastward-trending lineation, possibly a fault, is seen to pass near the deposit.

As yet the mineralogy of the deposit is not well known, especially in the part of the deposit beneath the zone of weathering. Radioactive minerals have been completely leached from only the uppermost quarter of an inch. Beneath the corpletely leached zone, still in a strongly weathered zone, yellow secondary minerals are along joints and a few grains of a black shiny radioactive mineral are disseminated in the granite. Pyrite and a few grains of galena were also seen; grains of purple fluorite have been reported by the prospectors. The primary radioactive minerals so far identified are thorianite, uranothorianite, and thorite. The secondary radioactive minerals that have been identified are bassetite, novacekite, sklodowskite, beta-uranophane, and gurmite.

During the fall of 1955 the deposit was explored by diamond drilling by the Climax Molybdenum Company. The company has not announced its future plans, but it is thought that the company will at least do further exploration during 1956. 
I and I group

The I and I group, consisting of the I and I claims numbers 3, 4, and 5, is located to the north of and adjoining the Cub group (fig. 5). The claims were staked by Lester A. Hollenbeak and Irma Hollenbeak of Ketchikan during June 1955.

Granite, eut by a few thin pegmatite dikes and quartz veinlets, appears to underlie the entire I and I group. On the I and I number 5 elaim, granite stands in bold outerops broken by numerous joints; on the I and I claims numbers 3 and 4 , it is mostly covered by vegetation and soil, but the cover is thin along a ridge that runs the length of the claims (fig. 6).

Twenty-three radioactivity anomalies have been found on the I and I claims numbers 3 and 4, but only one anomaly has been found on claim number 5. The distribution of the anomalies on claims 3 and 4 is show on figure 6, which is taken from a map made by pace and compass by J. A. Williams of the Alaska Territorial Department of Mines. The anomalies are in three. groups and each group has a trend of N. $50^{\circ}$ W. to N. $70^{\circ}$ W. Several parallel structures with this same trend are clearly visible on the aerial photograph of the area. An examination of the anomalies on the $I$ and $L$ group revealed either a pegmatite dike or a quartz veinlet in close proximity to each anomaly. The quartz in the quartz veinlets appears identical to the quartz that occurs in the center of the few pegmatites that are zoned, and indicates that the two types of structures are related in origin. Usually the greatest radioactivity occurs immediately alongside the pegmatite dike (including the quartz veinlets) or, when two pegmatites are very close together, in the country roek between the pegmatites. The radioactivity 


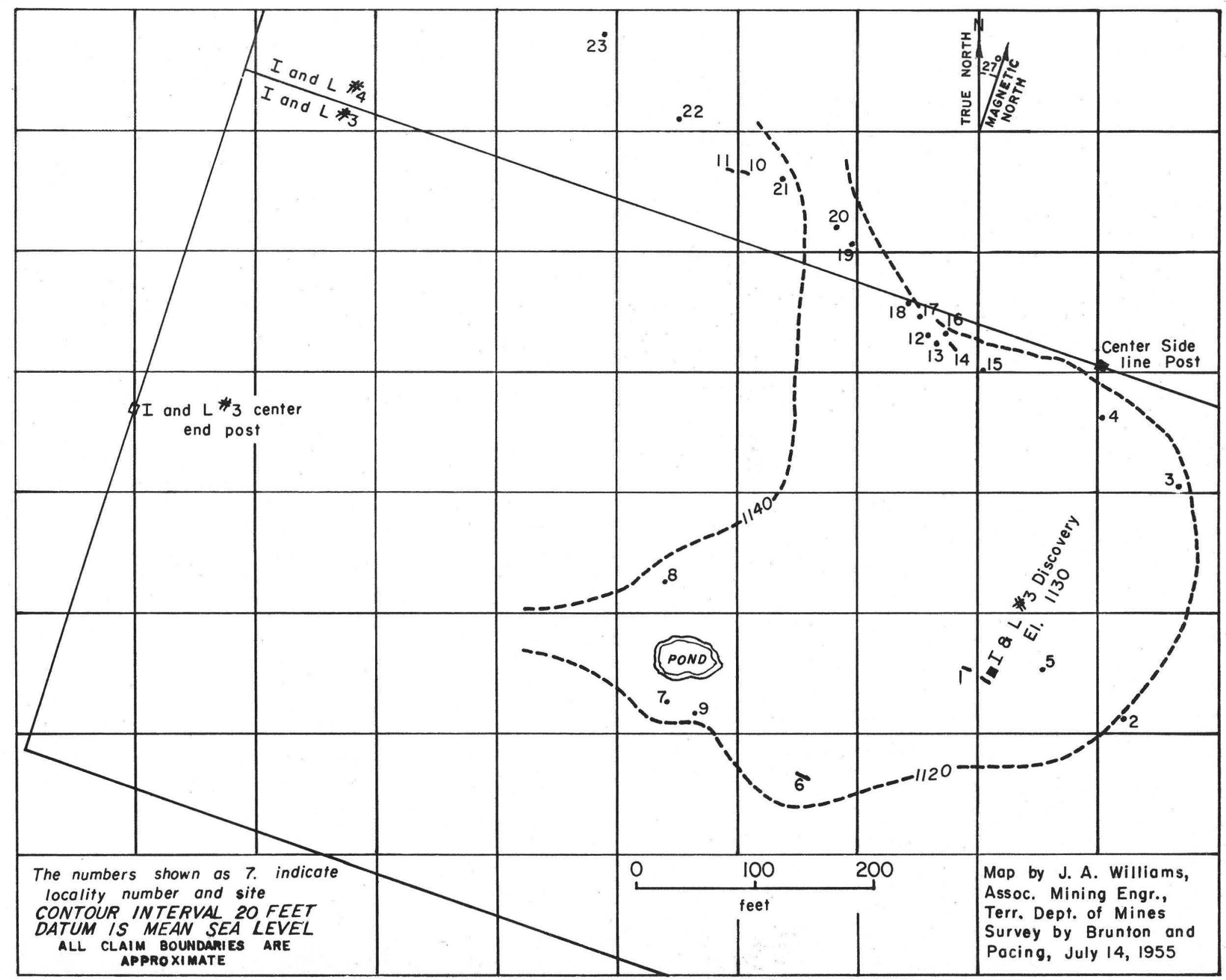

Figure 6. --Sketch map showing radioactivity anomalies on the 1 and L claims 3 and 4 
anomalies and related structures on the I and I group are all very small; the maximum width of high radioactivity is about 6 inches, and generally the anomalous zone is only I or 2 inches wide. At one locality where a pegmatite dike splits into several branches, the associated radioactivity is high through a width of nearly 2 feet, but nevertheless concentrated in several thin zones.

Hand samples from the anomalies on the I and I group contain from 0.05 to 6.0 pereent equivaIent uranium as determined by A. E. Glover of the Territorial Department of Mines assay office in Ketehikan. Fluorimetric assays on hand specimens show from 0.048 to 2.30 pereent $\mathrm{U}_{3} \mathrm{O}_{8}$. Two hand samples from localities 16 and 18 (fig. 6) were sent to the Geologieal Survey laboratories at College, Alaska, and Washington, D.C. The sample from locality 16 contained about 1.7 percent equivalent uranium, and the sample from locality 18 contained about 2.4 percent equivalent uranium. The radioactive mineral was determined by the college laboratory to be brannerite and showed on the spectroseope that $U$ and $T i$ are major constituents and that $\mathrm{Pb}, \mathrm{F}, \mathrm{Mn}, \mathrm{Ca}$, and $\mathrm{Y}$ are minor constituents. A spectroscopic analysis of the entire sample indicated that $\mathrm{Na}, \mathrm{U}, \mathrm{Al}$, and $\mathrm{Fe}$, were major constituents and $\mathrm{Y}, \mathrm{Ce}, \mathrm{Mn}$, and $\mathrm{Mb}$ were minor constituents. The laboratory in Washington (analysts: Katherine E. Valentine and Evelyn Cisney) reported the following on the specimen from locality 16: "physical and optical properties and X-ray diffraction patterns of the mineral suggest that it is a metamict columbate-tantalate. The X-ray spindles were analyzed spectrographically." Specimen 18 was determined to be brannerite. 
The owners of the I and. I group have done a little prospecting on the surfase but no subsurface work. They have signed a. contract with Union Carbide Nuelear Company, and milling tests were made on ore samples in 1955.

\section{Little Ray group}

The Iittle Ray group, consisting of the Little Ray, Annie, Irene, Marietta, Florence, Atom Rose, and Little Mary Rose claims (fig. 5) is east of and adjoins the I and I group. The claims were staked by "Pete" Cesnan, Joe Blazae, and Robert "Red" Dotson of Ketchikan. Except for the ridgetop area on the Little Mary Rose claim, the Little Ray group is heavily covered by vegetation, and only rarely is an outerop seen. Granite is the dominant rock type underlying the claims insofar as could be determined. A small dike of fine-grained basic rock erops out on the Little Mary Rose claim.

Several radioactivity anomalies were found on the Little Ray group all occurring along a persistent structure (possible two parallel structures that have not been identified but are believed to be fault traces) that trends about $\mathbb{N} \cdot 70^{\circ}$ W. and appears to be a continuation of the most prominent structure on the I and I group. The anomalies are adjacent to or within pegmatite dikes of two types. One type is zoned and consists of borders of a mafic mineral (probably hormblende) with feldspar and quartz in the center; the other type consists of quartz and feldspar in equant crystals. The exposed areas of the anomalies on the Little Ray group are small, and readings on a scintillation counter were about one-tenth of the readings obtained on the better anomalies on the I and I group. The mineralized rock 
on the Little Ray group contains a black shiny mineral (possibly brannerite), considerable purple fluorite, and scattered specular hematite. The granite adjacent to the mineralized zone has been altered to the extent that the mafic mineral is now chlorite. The areas of radioactivity anomalies seen on the group do not appear to have any commercial possibilities, but the structure or structures are persistent, and more prospecting should be done along it with the hope that a larger and high-grade ore shoot or a stockwork of low grade material will be found.

\section{Carol Anne group}

The Carol Anne group, consisting of two and a fraction claims, is located between the Iittle Ray group and the West Arm of Kendrick Bay (fig. 5). The claims were staked by William Juses, John Worthington, and Kenneth McKern of Ketchikan. The lower part of the area is heavily covered by vegetation and the upper part of the area is partly covered by vegetation. The upper part of the claims is underlain by granite and the lower part by diorite and andesitic dike rocks. The nature of the contact be tween the rock types could not be determined because of poor exposures.

Several radioactivity anomalies were found on the Carol Anne group along a structure that trends about N. $65^{\circ} \mathrm{W}$. The structure, believed to be a fault, is parallel to the structures on the little Ray group and is probably related in origin, but the mineralized rock is of different appearance.

The radioactive rock in the upper part of the group, where the structure cuts granite, occurs as thin veins or dikes that weather in relief above the surface of the granite. It is reddish fine-grained rock in which none of the constituents are identifiable with a hand lens. The color suggests garnet or 
hematite. It is only weakly radioactive but loeally the veins (or dikes) form a stockwork so that at one locality nearly half of a five-footwide zone of rock is vein material. A specimen of the radioative rock contained only 0.038 percent equivalent uranium. The impervious nature of the rock suggests that there has been very little leaching due to weathering.

In the lower part of the Carol Anne group the anomalies are due to material similar in appearanee to that in the upper part of the group, but the veins appear to be more deeply weathered along fractures and oecur with appreciable amounts of purple fluorite, pyrite, and very dark quartz. However, even the best of the anomalies is only about as radioactive as the best of the anomalies on the Little Ray group and does not appear to have commercial possibilities. Two hand samples taken from two pits on the structure contain 0.041 and 0.13 pereent equivalent uranium. Chemieal analysis on two samples colleeted from the Carol Anne group by J. A. Williams of the Alaska Territorial Department of Mines gave 0.02 and 0.07 percent uranium. More prospecting should be done on the Carol Anne group with emphasis on attempting to find localities where the branching of the vein structure has produced stockworks of considerable width.

\section{Other claims}

Several other claims are known to the writers in the Kendrick BayBokan Mountain area but have not been visited. Radioactivity anomalies have been found and the area staked between the West Arm of Kendrick Bay and Gardner Bay. It is believed to be an extension of the same possible fault structure that is locally radioactive in the Carol Anne group. Other claims have been staked south of Bokan Mountain near Hessa Lake. 
West of Bokan Mountain is a slightly radioactive deposit of purple fluorite along a fault contact between granite and dark fine-grained metamorphic rocks. The deposit is small and apparently of low grade (E. M. MacKevett, oral communication). North of Bokan Mountain many claims have been staked on ground having radioactive material that is reported to contain thorium minerals.

\section{SUMMARY}

In 1955 the most important find of radioactive material was in the Kendriek Bay-Bokan Mountain area. Uranium and thorium mineralization oceurred along a zone that extends from Bokan Mountain to about 10 miles southeast; further prospecting activity may be expected to enlarge this area. One company has initiated drilling, but data on the potential ore reserves are not available.

To evaluate the radioactivity anomalies determined from airborne surveys made in 1955, it will be necessary to obtain more field data. It is very probable that many, if not 2.11 , of the anomalies may be related to acidie igneous masses containing slightly radioactive accessory minerals such as zircon. In general, the anomalies are in remote areas where the geology is little known. The determination of the source of the anomalies will be made as time and funds permit.

In the part of the Koyukuk Geosyncline region that was investigated the most likely source of radioactive materials appears to be in the upper unit of the border facies of Cretaceous sediments that contain conglomerates, carbonaceous sediments, and coal. 


\section{LITERATURE CITED}

Chapman, R。M。, and Saunders, R. H。, 1954, The Kathleen-Margaret (K-M) copper prospect on the Upper Maclaren River, Alaska: U. S. Geol. Survey cire. $332,5 \%$

Coats, R. R., 1944, Asbestos deposits of the Dahl Creek area, Kobuk RIver distriet, Alaska: U. S. Geol. Survey mimeographed report, 4 p.

Eakin, H. M。, 1916, The Yukon-Koyukuk region, Alaska: U. S. Geol. Survey Bu11. 631, $88 \mathrm{p}$. Bu11. $667,54 \mathrm{p}$.

1918, The Cosnaw Howitna region, Alaska: U. S. Geol. Survey

Mertie, J. B., Jr., 1937, The Yukon-Tanana region, Alaska: U. S. Geol. Survey Bu11. 872,276 p。

Moffit, F.H., 1912, Headwater regions of Gulkana and Susitna Rivers, Alaska, with accounts of the Valdez Creek and Chistochina placer districts: U. S. Geol. Survey Bull. 498, 82 p.

, 1927, The Iniskin-Chinitna Peninsula and the Snug Harbor distroit, Alaska: U. S. Geol. Survey Bull. 789, 71 p.

, 1935, Geology of the Tonsina district, Alaska: U. S. Geol. Survey Bull. $866,38 \mathrm{p}$.

Moxham, R. M. and Nelson, A. E., 1952, Reconnaissance for radioactive deposits in southmeentral AIaska, 1947-49: U. S. Geol. Survey Circ. 184, 13 p.

NeIson, A. E., West, W. S., and Matzko, J. J., 1954, Reconnaissance for radioactive deposits in eastern Alaska, 1952: U. S. Geol. Survey cirs. 348,21 p.

Patton, W. W., Jro, and BickeI, R. S.; 1956a, Geologic map and structure sections along part of the lower Yukon River, Alaska: U. S. Geol. Survey Mise. Geol. Inv. Map I-I97.

, 1956b, Geologic map and structure sections of the Shaktolik River area, Alakka: U. S. Geol. Survey Mise. Geol. Inv. Map $I-226$.

Payne, T. Go, 1955, Mesozoic and Cenozoic tectonic elements of Alaska: U. S. Geol. Survey Mise. Geol. Inv. Map I-84.

Ross, C. P., 1933, Mineral deposits near the West Fork of the Chulitna River, Alaska: U. S. Geol. Survey Bull. 849-E, p. 289-333. 
Schrader, F. C., with notes by W.J. Peters, 1904, A reconnaissanee in northern Alaska across the Rocky Mountains, along Koyukuk, John, Anaktuvuk, and Colville rivers and the Arctie coast to Cape IIsburne, in 1901: U. S. Geol. Survey Prof. Paper 20, 139 p.

Smith, P.S。, and Eakin, H. M., 1911, The Shungnak region, Kobuk Valley: U. S. Geol. Survey BuIl. 480-J, p. 271-305.

Smith, P. S., and Mertie, J. B., Jr., 1930, Geology and mineral resources of northwestern Alasia: U. S. Geol. Survey Bull. 815, 351 p.

Waring, G. A., 1934, Core drilling for coal in the Moose Creek area, Alaska: U. S. Ceol. Survey Bull. 857-E, p. 155-166.

West, W. S., 1954, Reconnaissance for radioactive deposits in the lower Yukon-Kuskokwim region, Alaska, 1952: U。 S. Geol. Survey Cire. 328, $10 \mathrm{p}$.

White, M. Go, West, W. S., Tolbert, G. E., Nelson, A. E., and Houston, J. R., 1952, Preliminary summary of reconnaissance for uranium in Alaska, 1951: U. S. Geol. Survey Cire. 196, 17 p.

White, M. G., 1950, Examination for radioactivity in a copper-lode prospect on Ruby Creek, Kobuk River VaIley, Alaska: U. S. Geol. Survey Trace Elements Inv. Rept. 76-A, 8 p. 